\title{
Population genetic structure of the malaria vector Anopheles funestus, in a recently re-colonized area of the Senegal River basin and human-induced environmental changes
}

\author{
Badara Samb ${ }^{1,2}$, Ibrahima Dia ${ }^{2 *}$ Lassana Konate ${ }^{1}$, Diego Ayala ${ }^{3,5}$, Didier Fontenille $e^{3}$ and Anna Cohuet ${ }^{3,4}$
}

\begin{abstract}
Background: Anopheles funestus is one of the major malaria vectors in tropical Africa. Because of several cycles of drought events that occurred during the 1970s, this species had disappeared from many parts of sahelian Africa, including the Senegal River basin. However, this zone has been re-colonized during the last decade by An. funestus, following the implementation of two dams on the Senegal River. Previous studies in that area revealed heterogeneity at the biological and chromosomal level among these recent populations.

Methods: Here, we studied the genetic structure of the newly established mosquito populations using eleven microsatellite markers in four villages of the Senegal River basin and compared it to another An. funestus population located in the sudanian domain.

Results: Our results presume Hardy Weinberg equilibrium in each An. funestus population, suggesting a situation of panmixia. Moreover, no signal from bottleneck or population expansion was detected across populations. The tests of genetic differentiation between sites revealed a slight but significant division into three distinct genetic entities. Genetic distance between populations from the Senegal River basin and sudanian domain was correlated to geographical distance. In contrast, sub-division into the Senegal River basin was not correlated to geographic distance, rather to local adaptation.

Conclusions: The high genetic diversity among populations from Senegal River basin coupled with no evidence of bottleneck and with a gene flow with southern population suggests that the re-colonization was likely carried out by a massive and repeated stepping-stone dispersion starting from the neighboring areas where An. funestus endured.
\end{abstract}

Keywords: Anopheles funestus, Re-emergent population, Population structure, Microsatellites, Senegal river basin

\section{Background}

Anopheles funestus Giles, 1900 is one of the major malaria vectors in tropical Africa with An. gambiae sensu stricto and An. arabiensis [1], being the primary malaria vector in some areas [2-5]. In Senegal, An. funestus has been already described in all bio-geographic zones [6] and exhibits a predominant role in malaria transmission [7-9]. Following the recurrent droughts that have

\footnotetext{
*Correspondence: dia@pasteur.sn

2Unité d'entomologie médicale, Institut Pasteur de Dakar, 36 Avenue Pasteur, Dakar BP 220, Sénégal

Full list of author information is available at the end of the article
}

occurred during the 1970s, this species had disappeared from many parts of sahelian Africa, including the Senegal River basin, in consequence of the disappearance of its specific breeding sites [10]. However, after more than three decades of absence, the re-emergence of An. funestus was reported at the beginning of this century in the low valley of the Senegal River [11]. The hydroagricultural implementations following the start-up of the Diama dam are highly suspected to create favourable breeding places for the re-establishment of An. funestus $[9,12]$. This re-colonization had thus given rise to the fear of recrudescence of the transmission and incidence

\section{Biomed Central}

(c) Samb et al.; licensee BioMed Central Ltd. This is an Open Access article distributed under the terms of the Creative Commons Attribution License (http://creativecommons.org/licenses/by/2.0), which permits unrestricted use, distribution, and reproduction in any medium, provided the original work is properly cited. 
of malaria in this area. An entomological survey carried out thereafter in the Senegal River basin showed heterogeneity of An. funestus populations in their anthropophily, densities and parity [9]. Because this species is known to be biologically and genetically highly polymorphic [13-17], these observations led us to suspect a potential genetic structure within the newly established An. funestus populations. Likewise, significant chromosomal differentiation not linked to geographical distance has been reported between the An. funestus populations from the Senegal River basin and those from the sudanian domain [12].

In the present study, we studied the genetic structure of the An. funestus populations in the Senegal River basin using microsatellite DNA markers. This set of molecular markers were demonstrated to be suitable tools for population genetics studies within this mosquito [1720]. We aimed at investigating the genetic diversity and the genetic structure of the newly established An. funestus populations in the Senegal River basin in comparison to a more southern population of this species.

\section{Methods}

\section{Study sites and mosquito collection}

The study was carried out in four villages located in the Senegal River Basin, in sahelian domain (Mbilor, Gankette Balla, Diaminar Keur Kane, Loboudou) and in the village of Dielmo, located in the sudanian domain (Figure 1). The re-emergence of An. funestus was previously observed in the four selected villages from the Senegal River basin and biological heterogeneities were observed between sites [9]. The village of Mbilor $\left(16^{\circ} 29^{\prime} \mathrm{N}, 15^{\circ} 33^{\prime} \mathrm{W}\right)$ is situated in the low valley of the Senegal River. A retention basin made by the Senegalese Sugarcane Company and derived from the Senegal River represents the unique source of permanent water, which represents the main breeding site of anopheline mosquitoes. The village of Gankette Balla $\left(15^{\circ} 58^{\prime} \mathrm{N}, 15^{\circ} 55^{\prime} \mathrm{W}\right)$, Diaminar Keur Kane $\left(16^{\circ} 00^{\prime} \mathrm{N}, 15^{\circ}\right.$ $\left.54^{\prime} \mathrm{W}\right)$ and Loboudou $\left(15^{\circ} 57^{\prime} \mathrm{N}, 15^{\circ} 55^{\prime} \mathrm{W}\right)$ are situated on the shores of The Guiers Lake. The association between the shores of the Guiers Lake and the development of fresh water plants represent the main breeding sites for An. funestus, being the predominant anopheline species collected [9]. Mosquito collections were carried out between October 2003 and September 2004 in these four villages.

Mosquitoes from the Senegal River basin populations were compared to Dielmo $\left(13^{\circ} 45^{\prime} \mathrm{N}, 16^{\circ} 25^{\prime} \mathrm{W}\right)$, located in a sudanian domain of central Senegal, on the marshy bank of a small permanent stream, where anopheline mosquitoes breed all year round. Specimens from Dielmo were collected during the rainy season in 2000, between July and October.
All mosquitoes were collected by indoor pyrethrum spraying in randomly selected human dwellings. After collection, An. funestus were identified morphologically [21] and stored individually in labelled tubes with desiccant for further molecular processing.

\section{DNA extraction, molecular species identification and microsatellite genotyping}

Genomic DNA was extracted from wings and legs of each individual mosquito following the protocol described by Morlais et al. [22]. DNA was then resuspended in sterile water in individual tubes. Morphological identification of An. funestus sensu stricto was confirmed by molecular methods [23,24]. Eleven microsatellite loci were selected from published An. funestus sequence data [25-28], based on their high polymorphism and no evidence for null alleles. These microsatellites were FunL, FunO, AFUB11, AFND19, AFND20, AFND32, FunQ, AFND40, AFND5, FunG and FunF.

PCR was performed for each locus individually in a $25 \mu \mathrm{l}$ reaction volume. The reaction mixture contained 1 $\mathrm{X}$ PCR buffer containing $1.5 \mathrm{mM} \mathrm{MgCl}_{2}$ (Promega, France), $0.2 \mathrm{mM}$ of each dNTP (Eurogentec, Belgium), $10 \mathrm{pmol}$ of each primer, $0.1 \mathrm{U}$ of Taq DNA polymerase (Promega, France) and approximately 5-10 ng of template DNA. The forward primer was labelled in 5 ' with either by Fam, Vic, Ned or Pet fluorescent markers to allow multiplex electrophoresis (Eurogentec, Belgium). Amplification was performed in a GeneAmp 9700 thermocycler (Applied Biosystems, France). Cycling conditions were: an initial denaturation step at $94^{\circ} \mathrm{C}$ for $2 \mathrm{~min}$ followed by 36 cycles of $30 \mathrm{~s}$ at $94^{\circ} \mathrm{C}, 30 \mathrm{~s}$ at $54^{\circ} \mathrm{C}, 30 \mathrm{~s}$ at $72^{\circ} \mathrm{C}$ and a final elongation step of $10 \mathrm{~min}$ at $72^{\circ} \mathrm{C}$. Amplified products were diluted and pooled for genotyping in AB3130 sequencer (Applied Biosystems, France). Alleles were sized relatively to an internal size standard using GENEMAPPER v4.0 (Applied Biosystems, France).

\section{Data analysis}

For each locus and each population sample, heterozygosity was computed using GENETIX v.4.05 [29] and the number of alleles were computed using FSTAT v.2.9.3.2 [30]. FSTAT and GENEPOP v.4.0.3 [31] were used to assess the deviation from Hardy-Weinberg equilibrium at each locus, each population sample, and overall as indicated by the inbreeding coefficient $\left(F_{I S}\right)$. Linkage disequilibrium between pairs of microsatellite loci was assessed using FSTAT v.2.9.3.2 [30]. Significance was tested using the randomization approach implemented in FSTAT with Bonferroni-adjusted $P$-values.

Genetic differentiation between populations was assessed by estimating Wright's $F$-statistics [32], calculated according to Weir \& Cockerham [33]. Statistical significance of $F_{S T}$ 


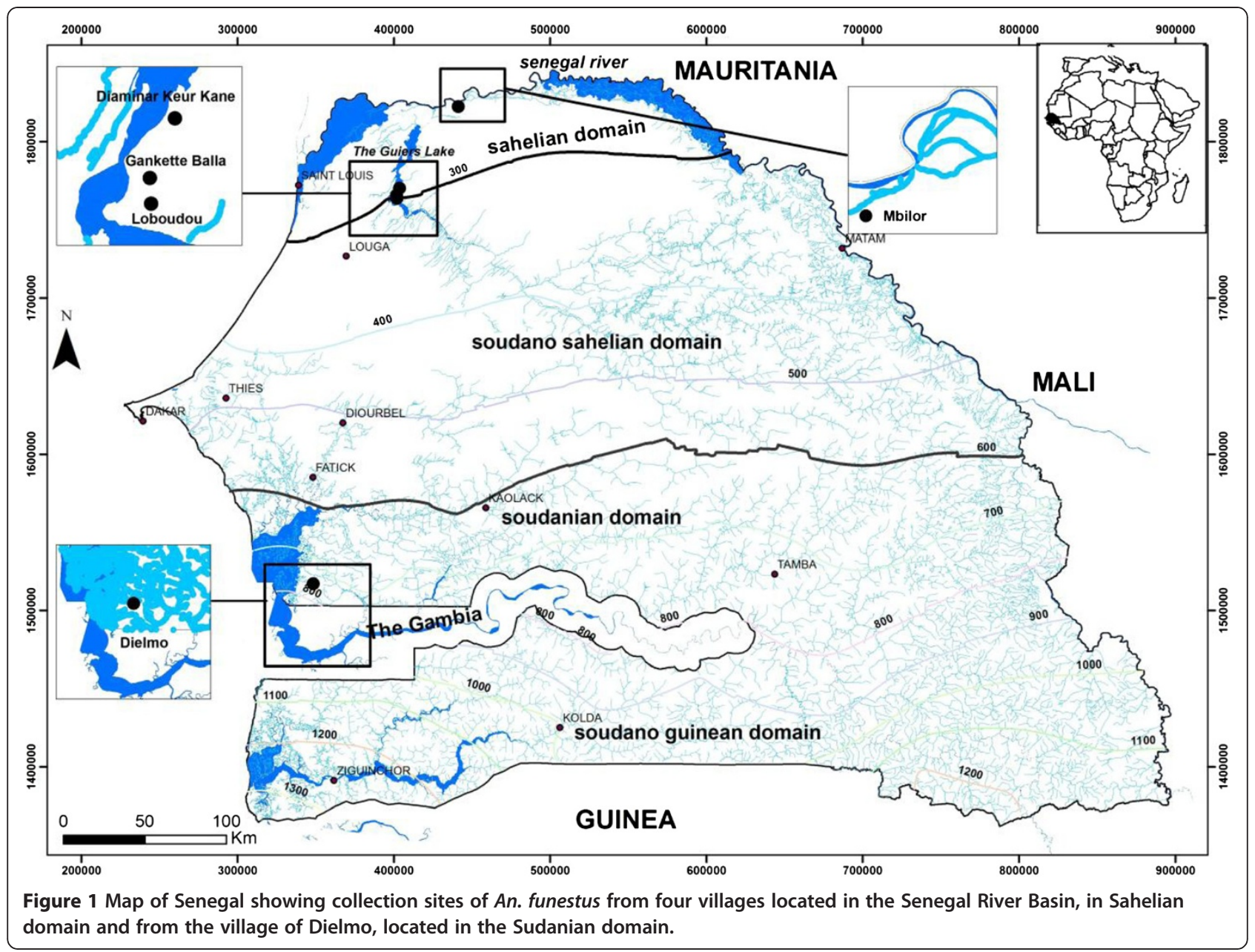

was assessed using G-based exact tests for genotypic differentiation [34], available in GENEPOP.

Because demographic instability such as recent population bottleneck and/or expansion might bias genetic differentiation, heterozygosity tests were implemented to test for Mutation-Drift Equilibrium (MDE) using BOTTLENECK V1.2.02 [35]. At selectively neutral loci, the expected heterozygosities calculated from allele frequency data $(\mathrm{He})$ and from the number of alleles and sample sizes $(\mathrm{Heq})$ are expected not to be significantly different $(H \mathrm{e} \approx H \mathrm{eq})$ in a population at MDE. If a population experiences a bottleneck, rare alleles will be lost by genetic drift, and Heq will decrease faster than $\mathrm{He}(\mathrm{He}>\mathrm{Heq})$. The resulting apparent excess of heterozygotes is an indicator of a recent bottleneck event, while the opposite $(H \mathrm{e}<\mathrm{Heq})$ may suggest population expansion. Estimates of expected heterozygosity under MDE were calculated using two mutation models for microsatellite evolution: the Two Phased Mutation model (TPM) [36] and the Stepwise Mutation Model (SMM) [37]. Wilcoxon signed rank tests were used to determine whether deviations from MDE were statistically significant.
We applied a Bayesian model-based clustering algorithm to infer population structure and to assign individuals (probabilistically) to clusters without a priori knowledge of population units and limits. This approach, implemented in STRUCTURE v2.2 [38], uses individual multilocus genotype data to cluster individuals into $K$ groups while minimising Hardy-Weinberg disequilibrium and gametic phase disequilibrium between loci within groups [39]. In STRUCTURE v 2.2, the number of distinct genetic clusters in the data set $(\mathrm{K})$ was estimated from 1 to 12 by the posterior log probability of data under each $K$, $\operatorname{Ln}[\operatorname{Pr}(\mathrm{X} \mid K)]$ [38]. Each run carried out 500,000 iterations after a burn-in period of 40,000 , using the admixture model and correlated allele frequencies. To check for convergence of the Markov chain Monte Carlo (MCMC), we performed over 5 replicates for each value of $K$ and then checked the consistency of results [40]. The estimated number of clusters $(K)$ was taken to be the value of $K$ with the highest $\operatorname{Pr}(\mathrm{X} \mid K)$ [39].

Groups of populations were defined according to STRUCTURE results and the hierarchical genetic variation 
Table 1 Genetic Variability at 11 microsatellites loci in Anopheles funestus from Senegal

\begin{tabular}{|c|c|c|c|c|c|c|c|}
\hline \multirow{2}{*}{\multicolumn{2}{|c|}{$\begin{array}{l}\text { Locus } \\
\text { (chromosomal } \\
\text { location) }\end{array}$}} & \multicolumn{6}{|c|}{ Populations } \\
\hline & & \multirow{2}{*}{$\begin{array}{l}\text { Diaminar } \\
(N=48)\end{array}$} & \multirow{2}{*}{\multicolumn{2}{|c|}{$\begin{array}{l}\text { r Dielmo Gankette } \\
(\mathrm{N}=41)(\mathrm{N}=49)\end{array}$}} & \multirow{3}{*}{$\begin{array}{l}\text { Loboudou } \\
\qquad \begin{array}{c}(N=47) \\
6\end{array}\end{array}$} & \multirow{2}{*}{$\begin{array}{l}\text { Mbilor } \\
(\mathrm{N}=50)\end{array}$} & \multirow{2}{*}{$\begin{array}{l}\text { Overall } \\
(N=235)\end{array}$} \\
\hline & & & & & & & \\
\hline AFUB11 & Nall & 7 & 9 & 7 & & 7 & 9 \\
\hline \multirow[t]{2}{*}{$(2 \mathrm{~L})$} & $\mathrm{HO}$ & 0.5682 & 0.7576 & 0.5833 & 0.6383 & 0.4681 & 0.594 \\
\hline & Fis & 0.215 & -0.009 & 0.106 & 0.046 & 0.347 & 0.1530 \\
\hline FUNL & Nall & 10 & 11 & 7 & 9 & 9 & 15 \\
\hline \multirow[t]{2}{*}{$(2 \mathrm{~L})$} & $\mathrm{HO}$ & 0.8864 & 0.7813 & 0.8140 & 0.6444 & 0.9375 & 0.816 \\
\hline & Fis & -0.076 & 0.043 & 0.013 & 0.191 & -0.094 & 0.0175 \\
\hline FUNO & Nall & 9 & 7 & 8 & 7 & 8 & 10 \\
\hline \multirow[t]{2}{*}{ (2R) } & $\mathrm{HO}$ & 0.7381 & 0.8125 & 0.7083 & 0.8085 & 0.8298 & 0.778 \\
\hline & Fis & -0.010 & -0.062 & -0.036 & -0.114 & -0.102 & -0.0363 \\
\hline AFND19 & Nall & 11 & 8 & 11 & 11 & 9 & 13 \\
\hline \multirow[t]{2}{*}{ (3R) } & $\mathrm{HO}$ & 0.5870 & 0.7179 & 0.7234 & 0.7179 & 0.7200 & 0.692 \\
\hline & Fis & 0.305 & 0.010 & 0.137 & 0.127 & 0.141 & 0.1673 \\
\hline AFND20 & Nall & 8 & 8 & 7 & 8 & 6 & 10 \\
\hline \multirow[t]{2}{*}{ (3R) } & $\mathrm{HO}$ & 0.7500 & 0.7949 & 0.7234 & 0.7500 & 0.6800 & 0.736 \\
\hline & Fis & -0.045 & -0.062 & 0.049 & 0.052 & 0.059 & 0.0232 \\
\hline AFND32 & Nall & 10 & 10 & 9 & 8 & 9 & 15 \\
\hline \multirow[t]{2}{*}{ (2R) } & $\mathrm{HO}$ & 0.7609 & 0.7750 & 0.8723 & 0.8974 & 0.7000 & 0.797 \\
\hline & Fis & 0.101 & 0.081 & -0.049 & -0.073 & 0.102 & 0.0535 \\
\hline FUNQ & Nall & 3 & 4 & 4 & 5 & 4 & 6 \\
\hline \multirow[t]{2}{*}{$(X)$} & $\mathrm{HO}$ & 0.5000 & 0.6500 & 0.4681 & 0.5128 & 0.6600 & 0.559 \\
\hline & Fis & 0.109 & 0.081 & 0.156 & 0.184 & -0.021 & 0.1162 \\
\hline AFND40 & Nall & 6 & 7 & 7 & 7 & 5 & 8 \\
\hline \multirow[t]{2}{*}{$(2 \mathrm{R})$} & $\mathrm{HO}$ & 0.8889 & 0.7250 & 0.8000 & 0.7273 & 0.7292 & 0.775 \\
\hline & Fis & -0.146 & -0.022 & -0.051 & 0.085 & -0.001 & -0.0182 \\
\hline AFND5 & Nall & 5 & 6 & 5 & 5 & 5 & 6 \\
\hline \multirow[t]{2}{*}{$(2 \mathrm{R})$} & $\mathrm{HO}$ & 0.3913 & 0.5000 & 0.5217 & 0.4783 & 0.4286 & 0.463 \\
\hline & Fis & 0.246 & 0.141 & 0.039 & 0.211 & 0.089 & 0.1493 \\
\hline FUNF & Nall & 5 & 7 & 4 & 6 & 5 & 7 \\
\hline \multirow[t]{2}{*}{$(3 \mathrm{~L})$} & $\mathrm{HO}$ & 0.7391 & 0.7500 & 0.7174 & 0.6739 & 0.6122 & 0.696 \\
\hline & Fis & -0.138 & 0.028 & -0.114 & 0.020 & -0.067 & -0.0285 \\
\hline FUNG & Nall & 10 & 8 & 9 & 9 & 8 & 12 \\
\hline \multirow[t]{2}{*}{ (3R) } & $\mathrm{HO}$ & 0.8043 & 0.7500 & 0.8261 & 0.7826 & 0.7917 & 0.792 \\
\hline & Fis & 0.063 & -0.020 & 0.020 & 0.078 & 0.070 & 0.0854 \\
\hline Mean & Nall & 7.6 & 7.7 & 7.09 & 7.3 & 6.8 & 10 \\
\hline across all loci $H$ & $\mathrm{HO}$ & 0.6922 & 0.7286 & 0.7053 & 0.6938 & 0.6870 & 0.700 \\
\hline & Fis & 0.054 & 0.017 & 0.023 & 0.070 & 0.048 & 0.06 \\
\hline
\end{tabular}

existing within groups of populations and within populations was analyzed by Analysis of Molecular Variance (AMOVA) using Arlequin version 3.5 [41].

The correlation between genetic and geographical distances was assessed by the regression of $F_{S T} /\left(1-F_{S T}\right)$
Table 2 Heterozygosity tests in An. funestus populations from Senegal

\begin{tabular}{lcccc}
\hline Locality & \multicolumn{3}{c}{ TPM } & SMM \\
\cline { 2 - 4 } & $\mathbf{7 0 \%}$ & $\mathbf{8 0 \%}$ & $\mathbf{9 0 \%}$ & \\
\hline Diaminar & 3 & 4 & 4 & 7 \\
Dielmo & 7 & 7 & 7 & $10^{* *}$ \\
Gankette & 3 & 3 & 4 & 7 \\
Loboudou & $1^{* *}$ & $3^{*}$ & 7 & 8 \\
Mbilor & 2 & 5 & 5 & 6
\end{tabular}

TPM: Two-Phase mutation Model. SMM: Stepwise Mutation Model. ${ }^{* P}<0.05,{ }^{*} \mathrm{P}<0.01$ (two-tailed Wilcoxon signed-rank test P-values for deviation from MDE) after correction for multiple tests. The number of microsatellite loci showing heterozygote deficiency (e.g., $\mathrm{He}<\mathrm{Heq}$ ) out of 11 test loci is given.

on the logarithm (ln) of geographical distance [42], and tested using the Mantel test available in GENEPOP. Dispersion ability was estimated by the "neighborhood size," Do2, that is, the product of the effective population density (D) by the average squared parent offspring distance $\left(\sigma^{2}\right)[42]$.

Kruskal-Wallis test was used to compare the average number of alleles and the average proportions of heterozygosity between populations using XLSAT Pro $2006^{\circledR}$.

The Bonferroni correction procedure [43] was applied to evaluate significance when multiple tests were performed.

\section{Results}

\section{Genetic variability}

Genotypes of 235 An. funestus females were scored at 11 microsatellite loci. These microsatellite loci were highly polymorphic with a number of distinct alleles per locus ranging from 6 (FUNQ, AFND5) to 15 (AFND32, FUNL) in our five populations (Table 1). The average number of alleles per locus ranged from 6.8 to 7.7 and was not significantly different among populations $(P=0.83)$. Mean observed heterozygosity across all loci ranged from 0.68 to 0.72 and was not significantly different among populations $(P=0.89)$. Heterozygosity tests were performed to explore

Table 3 Estimates of $\boldsymbol{F}_{S T}$ values and their statistical significance (Bolded values)

\begin{tabular}{lcccc}
\hline Populations & Diaminar & Dielmo & Gankette & Loboudou \\
\hline Diaminar & & - & - & - \\
Dielmo & $\mathbf{0 . 0 4 6 3}$ & & - & - \\
Gankette & -0.0004 & $\mathbf{0 . 0 4 9 0}$ & & - \\
Loboudou & -0.0030 & $\mathbf{0 . 0 4 2 9}$ & 0.0055 & \\
Mbilor & $\mathbf{0 . 0 0 9 2}$ & $\mathbf{0 . 0 5 1 9}$ & $\mathbf{0 . 0 1 2 5}$ & $\mathbf{0 . 0 1 4 0}$ \\
\hline
\end{tabular}

$P$ - values obtained after 10.000 permutations; Indicative adjusted nominal level $(5 \%)$ for multiple (10) comparisons is 0.005 .

$P<0.0001$ for Bolded values. 
demographic stability in An. funestus populations and compliance to mutation-drift equilibrium. Significant deviations from mutation-drift equilibrium, as a result of heterozygote excess, was found in a population of Loboudou, when the studies were performed under TPM 70\% and TPM 90\% model. In Dielmo, significant deviations associated with strong heterozygote deficiencies were detected under SMM model. For the populations of Gankette, Diaminar and Mbilor, no deviation from MDE was found (Table 2).

\section{Hardy-Weinberg and linkage disequilibrium}

When the pooled samples were analyzed as a single population, 3 (AFUB11, AFND19 and FUNQ) of 11 loci showed significant deviations from Hardy-Weinberg equilibrium due to significant heterozygote deficiency (Table 1). When considering all loci, no deviation from Hardy-Weinberg equilibrium was observed within each population studied. However, significant deviation from Hardy-Weinberg expectations was observed for loci AFUB11 and AFND19 respectively in populations of Mbilor and Diaminar after the Bonferroni correction was applied. These deviations from Hardy-Weinberg expectations were associated with heterozygote deficiency (Table 1). No linkage disequilibrium was observed in any pair of loci $(6600$ permutations, $P>0.05)$.

\section{Genetic differentiation and structure analysis}

The levels of genetic differentiation between pairs of populations were estimated by $F_{S T}$ values. Table 3 shows $F_{S T}$ estimates for all pairwise population comparisons. The values of $F_{S T}$ between pairwise population comparisons for all loci ranged from 0 (Diaminar-Gankette) to 0.0519 (Dielmo-Mbilor). The highest $F_{S T}$ estimates were obtained between the most distant populations. $F_{S T}$ estimates were highly significant $\left(P<10^{-4}\right)$ between Dielmo and the populations of the Senegal River basin and between Mbilor and the populations around Guiers Lake area (Diaminar, Gankette and Loboudou). After all, only three comparisons were not significant after Bonferroni correction: Diaminar-Loboudou $(P>0.005)$, Diaminar-Gankette $(P>0.005)$, and Gankette-Loboudou $(P>0.005)$.

Structure $v$ 2.2. provided consistent results over 5 replicated runs tested for each $K$. The probability of the data $(\operatorname{Ln} \operatorname{Pr}(\mathrm{X} \mid K))$ greatly increased from $K=1$ to $K=2$, and then reached a maximum value at $K=3$, after which the values decreased gradually (Figure 2). Thus, in agreement with results based on $F_{S T}$, the most likely number of genetic clusters in the dataset is $K=3$ (Figure 2).

The analysis of molecular variance (AMOVA) of all the eleven microsatellites then confirmed the differentiation and structure analysis with the variation within

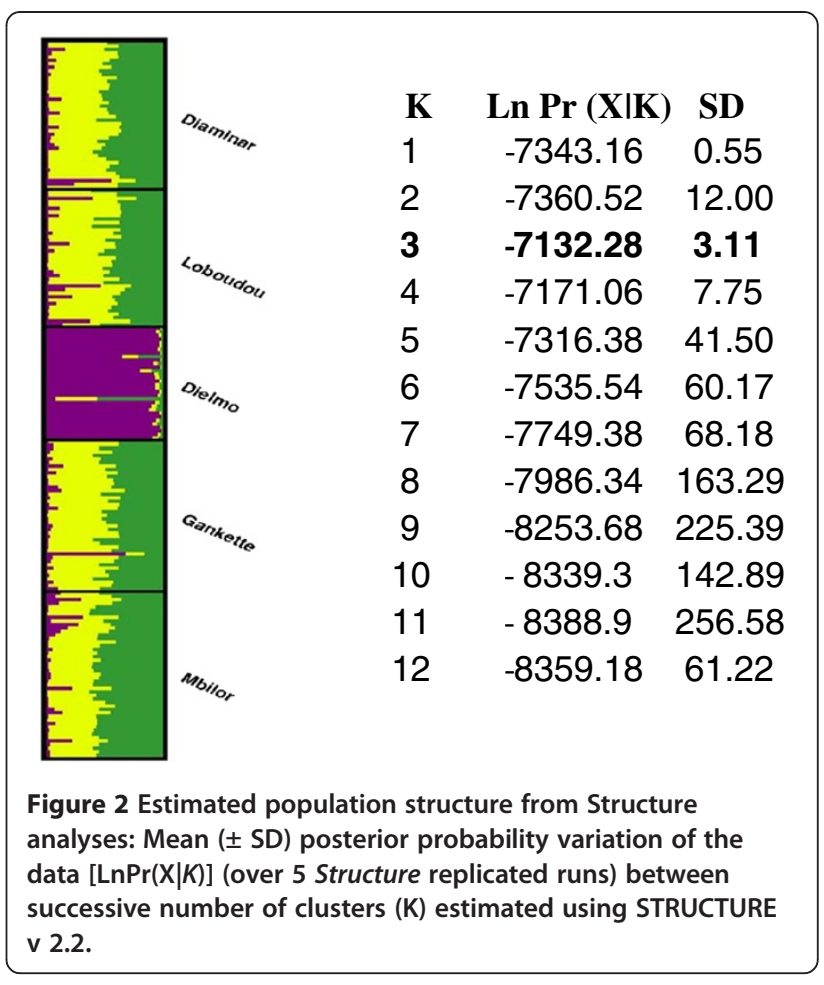

individuals, among individuals within populations, among populations within groups and among groups being $92.73 \%, 4.21 \%, 0.08 \%$, and $2.97 \%$ respectively (Table 4). AMOVA showed that the variation among populations within groups explained only $0.06 \%$ of the total variance while the variation from among individuals within populations and within individuals explained $4.21 \%$ and $92.73 \%$ of the total variation, respectively.

\section{Isolation by distance}

Isolation by distance was tested and showed a positive and significant $\left(R^{2}=0.76, P=0.02\right)$ correlation between $F_{S T} /\left(1-F_{S T}\right)$ and the logarithm of distance, when considering the five villages $\left(D \sigma^{2}=7.23\right)$ (Figure 3$)$. The

Table 4 Analysis of molecular variance (AMOVA) of 11 microsatellite loci in the An. funestus populations from Senegal, for $\mathbf{5}$ populations and $\mathbf{3}$ groups defined as (Dielmo/Mbilor/Diaminar, Gankette and Loboudou)

\begin{tabular}{lrcc}
\hline Source of variation & $\begin{array}{r}\text { Sum of } \\
\text { squares }\end{array}$ & $\begin{array}{c}\text { Variance } \\
\text { components }\end{array}$ & $\begin{array}{c}\text { Percentage } \\
\text { variation }\end{array}$ \\
\hline Among groups & 39.166 & 0.12333 & 2.97159 \\
$\begin{array}{l}\text { Among populations within } \\
\text { groups }\end{array}$ & 8.986 & 0.00339 & 0.08157 \\
$\begin{array}{l}\text { Among individuals within } \\
\text { populations }\end{array}$ & 907.273 & 0.17487 & 4.21357 \\
Within individuals & 850.500 & 3.84868 & 92.73328 \\
Total & 1805.926 & 4.15026 & \\
\hline
\end{tabular}




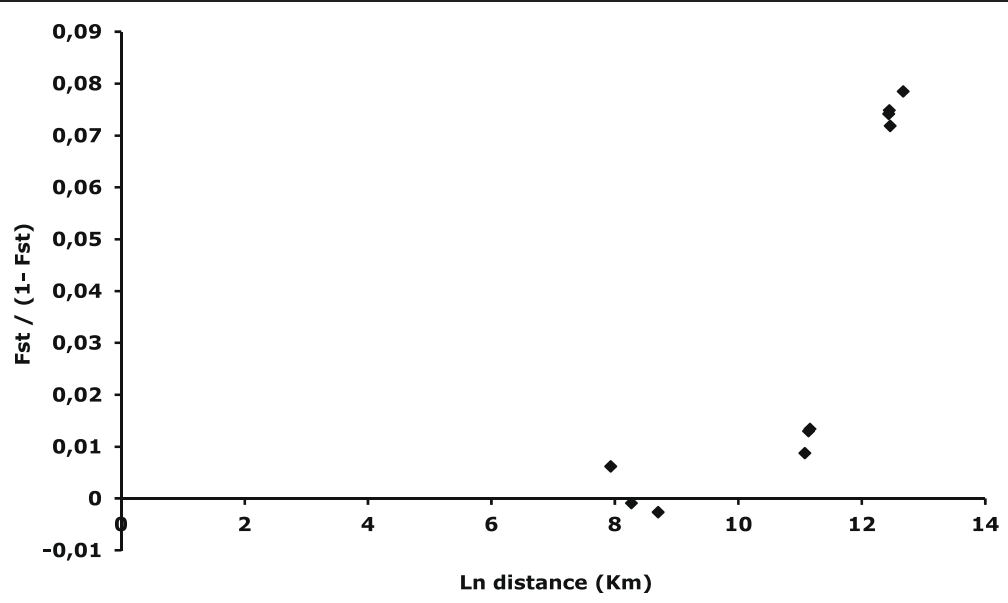

Figure 3 Correlation between $F_{\mathrm{ST}} /\left(1-F_{\mathrm{ST}}\right)$ and logarithm of distance (in $\mathrm{Km}$ ) for pair-wise comparisons of 5 Anopheles funestus populations from Senegal genotyped at 11 microsatellite loci.

correlation became non significant when considering only the An. funestus populations of the Senegal River basin $\left(\mathrm{R}^{2}=0.69, P=0.20\right)\left(\mathrm{D \sigma}^{2}=20.94\right)$.

\section{Discussion}

This study revealed genetic stability among the populations of Anopheles funestus in the Senegal River basin. Moreover, our results showed high levels of genetic diversity within the re-emergent populations of the Senegal River basin and a permanent population in the Sudanian domain. The comparable levels of genetic diversity between both areas confirmed the genetic stability of the newly established populations from the Senegal River basin. Furthermore, geographical distance seems to be the key factor for population genetic divergence, although, other factors could potentially play a role in the genetic differentiation among Senegal River basin populations. The high levels of gene flow denote important mosquito migration among populations.

The observed genetic stability of An. funestus populations from the Senegal River basin was at least unexpected. Indeed, after several decades of periodic droughts, and recent re-emergence of An. funestus, we predicted a genetic signal of bottleneck followed by population expansion, as reported elsewhere in An. gambiae [44]. The absence of such demographic signals may be explained by the noteworthy effective population size of the An. funestus population, which could promptly foster population equilibrium [45]. For instance, the large population size in Anopheles gambiae prevented any impact on the mosquito population structure after strong population selection (i.e. vector control measures, dry seasons) $[46,47]$. On the other hand, high migration rates between populations can also erase any genetic signal of natural selection [48]. Therefore, the absence of signal for bottleneck and demographic expansion may indicate that the re-colonization was massive and/or seasonally repeated. We then hypothesize that the gene flow between Senegal River basin and other $A n$. funestus populations may occur each year at the rainy season, when breeding sites are numerous and close enough to allow mosquito dispersal among populations.

Our results showed low but significant levels of genetic differentiation between populations of the Senegal River basin and those from the sudanian area. High levels of gene flow have been repeatedly reported on An. funestus and our estimates are consistent with previous studies on genetic structure of An. funestus populations in Senegal and other parts of Africa using microsatellites $[17,18,20,49,50]$. The important gene flow between An. funestus populations from the Senegal River basin and the sudanian population $(252 \mathrm{~km}$ apart), revealed by our analysis, indicate the existence of continuous populations of this malaria mosquito are inter-connected. Such observations were already reported in the other genetic studies in the populations of An. funestus [19,49,51,52] and An. gambiae s.l [53-56]. Therefore, these results reassert that the recolonization of An. funestus in the Senegal River basin was probably carried out by a step by step dispersion starting from the neighbouring areas where An. funestus had not disappeared.

The genetic analysis clearly distinguished between sahelian and sudanian populations. The genetic tests of isolation by distance suggested that genetic differences observed between domains are linked to the geographical distance. This is a common pattern in Anopheles [44,57,58] and particularly in Anopheles funestus [18,20,50,51]. In contrast, An. funestus 
populations from the Senegal River basin may be subdivided into two distinct genetic entities: populations around Guiers lake area (Diaminar, Gankette, Loboudou) and populations from the low valley of Senegal River (Mbilor). The existence of these three genetic entities (two in the Senegal River basin and one from the sudanian domain) was confirmed by different genetic approaches (i.e. Structure and AMOVA). When Dielmo was excluded from the isolation by distance analysis, geographical distance did not explain the genetic differentiation observed between Mbilor and populations around Guiers Lake area. Thereby, other factors rather than geographical distance should play a key role into the population structuration of An. funestus populations in the Senegal River basin. Chromosomal differentiation detected between An. funestus populations of the low valley of Senegal River and the Guiers Lake area (difference of frequency for the inversion 3La) [12] may be implicated in the structure observed as demonstrated in the An. funestus populations of Burkina Faso [17]. Because paracentric inversions are involved in the adaptation to various environments, the chromosomal differentiation detected between $A n$. funestus populations of the low valley of Senegal River and the Guiers Lake area [12] could be the consequence of different breeding sites, themselves consequences of different environmental changes induced by human activity.

\section{Conclusions}

Our study showed the existence of three genetically different subpopulations of An. funestus: populations around Guiers Lake area, populations from the low valley of Senegal River, and populations from Dielmo. The high genetic diversity among populations from the Senegal River basin coupled with no evidence of bottleneck and with a gene flow with the southern population suggested that the re-colonization was likely carried out by massive and repeated steppingstone dispersions starting from the neighbouring areas where An. funestus endured. Geographical distance is not the only factor involved in shaping of the genetic structure observed between the $A n$. funestus populations from the low valley of the Senegal River and The Guiers Lake area and we hypothesize that the different breeding sites created by human activities may have shaped chromosomal structuration and may explain the restricted but still occurring gene flow. Our study is therefore indicative of adaptation of malaria vectors to the environment modified by humans.

\section{Competing interests}

The authors declare that they have no competing interests.

\section{Authors' contributions}

ID, LK and DF designed and supervised the study. BS, ID and LK performed field activities. BS performed laboratory work under guidance of AC. BS, DA, $A C$ analyzed the data. BS, DA, ID and AC drafted and revised the manuscript. All authors approved the final version of the manuscript.

\section{Acknowledgments}

We are grateful to Malick Faye, Moussa Diagne, Omar Niang for technical assistance and help during field investigations and the villagers for their cooperation and their active participation in this study. The authors also acknowledge Kader Ba from the Institut des Sciences de la Terre, Dakar, Sénégal for his help in making the map of the study area and the PALFleuve programme. This study was supported by the French Ministry of Research through the PAL + program and the Institut Pasteur de Dakar.

\section{Author details}

'Département de Biologie animale Laboratoire d'écologie vectorielle et parasitaire, Université Cheikh Anta Diop de Dakar, Dakar-Fann BP 5005, Sénégal. Unité d'entomologie médicale, Institut Pasteur de Dakar, 36 Avenue Pasteur, Dakar BP 220, Sénégal. Institut de Recherche pour le Développement, Unité MIVEGEC (IRD 224-CNRS 5290-UM1-UM2), 34394, Montpellier Cedex 5 BP 64501, France. ${ }^{4}$ Institut de Recherche en Sciences de la Sante'-Direction Régionale de l'Ouest, Bobo Dioulasso, Burkina Faso. ${ }^{5}$ Department of Biological Sciences Eck Institute for Global Health, University of Notre Dame, Notre Dame, IN 46556, USA.

Received: 22 March 2012 Accepted: 21 August 2012

Published: 5 September 2012

\section{References}

1. Coetzee M, Fontenille D: Advances in the study of Anopheles funestus, a major vector of malaria in Africa. Insect Biochem Mol Biol 2004, 34:599-605.

2. Fontenille D, Lepers JP, Campbell GH, Coluzzi M, Rakotoarivony I, Coulanges P: Malaria transmission and vector biology in Manarintsoa, high plateaux of Madagascar. AmJTrop Med Hyg 1990, 43:107-115.

3. Mendis C, Jacobsen J, Gamage-Mendis A, Bule E, Dgedge M, Thompson R, Cuamba N, Barreto J, Begtrup K, Sinden R, Hogh B: Anopheles arabiensis and Anopheles funestus are equally important vectors of malaria in Matola coastal suburb of Maputo, southern Mozambique. Med Vet Entomol 2000, 14:171-180

4. Cohuet A, Simard F, Wondji CS, Antonio-Nkondjio C, Awono-Ambene P, Fontenille D: High malaria transmission intensity due to Anopheles funestus (Diptera: Culicidae) in a village of savannah-forest transition area in Cameroon. J Med Entomol 2004, 41:901-915.

5. Dabire KR, Baldet T, Diabate A, Dia I, Costantini C, Cohuet A, Guiguemde TR, Fontenille D: Anopheles funestus (Diptera: Culicidae) in a Humid Savannah Area of Western Burkina Faso: Bionomics, Insecticide Resistance Status, and Role in Malaria Transmission. J Med Entomol 2007, 44:990-997.

6. Diagne N, Fontenille D, Konate L, Faye O, Lamizana MT, Legros F, Molez JF, Trape JF: Les anophèles du Sénégal. Liste commentée et illustrée. Bull Soc Pathol Exot 1994, 87:267-277.

7. Fontenille D, Lochouarn L, Diagne N, Sokhna CS, Lemasson JJ, Diatta M, Konate L, Faye O, Rogier C, Trape JF: High annual and seasonal variations in malaria transmission by anophelines and vector species composition in Dielmo, a holoendemic area in Senegal. AmJTrop Med Hyg 1997 $56: 247-253$

8. Dia I, Diop T, Rakotoarivony I, Kengne P, Fontenille D: Bionomics of Anopheles gambiae Giles, Anopheles arabiensis Patton, Anopheles funestus Giles and Anopheles nili (Theobald) (Diptera: Culicidae) and transmission of Plasmodium falciparum in a Sudano-Guinean zone (Ngari, Senegal). $J$ Med Entomol 2003, 40:279-283.

9. Dia I, Konate L, Samb B, Sarr J, Diop A, Rogerie F, Faye M, Riveau G, Remoue F, Diallo M, Fontenille D: Bionomics of malaria vectors and relationship with malaria transmission and epidemiology in three physiographic zones in the Senegal River Basin. Acta Trop 2008, 105:145-153.

10. Mouchet J, Faye $\mathrm{O}$, Julvez J, Manguin S: Drought and malaria retreat in the Sahel West Africa. Lancet 1996, 348:1736. 
11. Konate L, Diop A, Sy N, Faye MN, Dieng Y, Izri A, Faye O, Mouchet J: Comeback of Anopheles funestus in Sahelian Senegal. Lancet 2001, 358:336.

12. Dia I, Samb B, Konate L, Fontenille D: Population structure of newly established Anopheles funestus populations in the Senegal River basin using paracentric chromosomal inversions. Acta Trop 2010, 115:90-94.

13. Boccoloni D, Sabatini A, Sanogo E, Sagnon N'f, Coluzzi M, Costantini C: Chromosomal and vectoriel heterogeneities in Anopheles funestus in Burkina Faso West Africa. Parassitologia 1994, 36(Supp I1)):20.

14. Lochouarn L, Dia I, Boccolini D, Coluzzi M, Fontenille D: Bionomical and cytogenetic heterogeneities of Anopheles funestus in Senegal. Trans Roy Soc Trop Med Hyg 1998, 92:607-612.

15. Costantini C, Sagnon N, Ilboudo-Sanogo E, Coluzzi M, Boccolini D: Chromosomal and bionomic heterogeneities suggest incipient speciation in Anopheles funestus from Burkina Faso. Parassitologia 1999, 41:595-611.

16. Dia I, Lochouarn L, Boccolini D, Costantini C, Fontenille D: Spatial and temporal variations of the chromosomal inversion polymorphism of Anopheles funestus in Senegal. Parasite 2000, 7:179-183.

17. Michel AP, Guelbeogo WM, Grushko O, Schemerhorn BJ, Kern M, Willard MB, Sagnon N'f, Costantini C, Besansky NJ: Molecular differentiation between chromosomally defined incipient species of Anopheles funestus. Insect Mol Biol 2005, 14:375-387.

18. Ayala D, Fontaine $C M$, Cohuet A, Fontenille $D$, Vitalis $R$, Simard F: Chromosomal Inversions Natural Selection and Adaptation in the Malaria Vector Anopheles funestus. Mol Biol Evol 2011, 28:745-758.

19. Braginets OP, Minakawa N, Mbogo CM, Yan G: Population genetic structure of the African malaria mosquito Anopheles funestus in Kenya. AmJTrop Med Hyg 2003, 69:303-308.

20. Cohuet A, Dia I, Simard F, Raymond M, Fontenille D: Population structure of the malaria vector Anopheles funestus in Senegal based on microsatellite and cytogenetic data. Insect Mol Biol 2004, 13:251-258.

21. Gillies MT, De Meillon B: The Anophelinae of Africa South of the Sahara (Ethiopian zoogeographical region). Publ South Afr Inst Med Res 1968, 54:343.

22. Morlais I, Ponçon N, Simard F, Cohuet A, Fontenille D: Intraspecific nucleotide variation in anopheles gambiae: new insights into the biology of malaria vectors. AmJTrop Med Hyg 2004, 71:795-802.

23. Koekemoer $L L$, Kamau L, Hunt RH, Coetzee M: A cocktail polymerase chain reaction assay to identify members of the Anopheles funestus (Diptera: Culicidae) group. AmJTrop Med Hyg 2002, 66:804-811.

24. Cohuet A, Simard F, Toto JC, Kengne P, Coetzee M, Fontenille D: Species identification within the Anopheles funestus group of malaria vectors in Cameroon and evidence for a new species. AmJTrop Med Hyg 2003, 69:200-205.

25. Sinkins SP, Hackett BJ, Costantini C, Vulule J, Ling YY, Collins FH, Besansky NJ: Isolation of polymorphic microsatellite loci from the malaria vector Anopheles funestus. Mol Ecol 2000, 9:490-492.

26. Sharakhov I, Braginets $O$, Grushko O, et al: 12 co-authors A microsatellite map of the African human malaria vector Anopheles funestus. $J$ Hered 2004, 95:29-34.

27. Cohuet A, Simard F, Berthomieu A, Raymond M, Fontenille D, Weill M: Isolation and characterisation of microsatellite DNA markers in the malaria vector Anopheles funestus. Mol Ecol Notes 2002, 2:498-500.

28. Bj S, Greeman S, Banks M, Vulule J, Sagnon N'f, Costantini C, Besansky NJ: Dinucleotide microsatellite markers from Anopheles funestus. Mol Ecol Notes 2003, 3:505-507.

29. Belkhir K, Borsa P, Chikhi L, Raufaste N, Bonhomme F: GENETIX 4.05, logiciel sous Windows TM pour la génétique des populations. In Laboratoire Génome, Populations, Interactions, CNRS UMR 5000. France: Université de Montpellier II, Montpellier; 2004. Available from [http://www.genetix.univmontp2.fr/genetix/intro.htm.

30. Goudet J: FSTAT version 2.9.3.2. A computer software to calculate Fstatistics. J Hered 1995, 86:485-486.

31. Raymond M, Rousset F: GENEPOP, Version 1.2. A population genetics software for exact tests and ecumenicism. J Hered 1995, 86:248-249.

32. Wright S: Evolution and Genetics of populations. In Variability within and among natural populations. Volume 4. Chicago: University of Chicago Press; 1978.
33. Weir BS, Cockerham CC: Estimating F-statistics for the analysis of population structure. Evolution 1984, 38:1358-1370.

34. Goudet J, Raymond M, De Meeüs T, Rousset F: Testing differentiation in diploid populations. Genetics 1996, 144:1933-1940.

35. Cornuet JM, Luikart G: Description and power analysis of two tests for detecting recent population bottlenecks from allele frequency data. Genetics 1996, 144:2001-2014.

36. Kimura M, Ohta T: Stepwise mutation model and distribution of allelic frequencies in a finite population. Proc Natl Acad Sci USA 1978, 75:2868-2872.

37. Di Rienzo A, Peterson AC, Garza JC, Valdes AM, Slatkin M, Freimer NB: Mutational processes of simple-sequence repeat loci in human populations. Proc Natl Acad Sci USA 1994, 91:3166-3170.

38. Pritchard JK, Stephens M, Donnelly P: Inference of population structure using multilocus genotype data. Genetics 2000, 155:945-959.

39. Falush D, Stephens M, Pritchard JK: Inference of population structure using multilocus genotype data: linked loci and correlated allele frequencies. Genetics 2003, 164:1567-1587.

40. Fontaine MC, Baird SJE, Piry S, et al: 19 co-authors Rise of oceanographic barriers in continuous populations of a cetacean: the genetic structure of harbour porpoises in Old World waters. BMC Biol 2007, 5:30.

41. Excoffier L, Lischer HEL: Arlequin suite version 3.5: A new series of programs to perform population genetics analyses under Linux and Windows. Mol Ecol Resour 2010, 10:564-567.

42. Rousset F: Genetic differentiation and estimation of gene flow from Fstatistics under isolation by distance. Genetics 1997, 145:1219-1228.

43. Holm S: A simple sequentially rejective multiple test procedure. Scand J Stat 1979, 6:65-70.

44. Lehmann T, Licht M, Elissa N, Maega BT, Chimumbwa JM, Watsenga FT, Wondji CS, Simard F, Hawley WA: Population Structure of Anopheles gambiae in Africa. $J$ Hered 2003, 94:133-147.

45. Michel AP, Grushko O, Guelbeogo WM, Sagnon N'F, Costantini C, Besansky NJ: Effective population size of Anopheles funestus chromosomal forms in Burkina Faso. Malaria J 2006, 5:115.

46. Simard F, Lehmann T, Lemasson JJ, Diatta M, Fontenille D: Persistence of Anopheles arabiensis during the severe dry season conditions in Senegal: an indirect approach using microsatellite loci. Insect Mol Biol 2000, 9(5):467-479.

47. Wondji C, Simard F, Lehmann T, Fondjo E, Samè-Ekobo A, Fontenille D: Impact of insecticide-treated bed nets implementation on the genetic structure of Anopheles arabiensis in an area of irrigated rice fields in the Sahelian region of Cameroon. Mol Ecol 2005, 14:3683-3693.

48. Lenormand T: Gene flow and the limits to natural selection. Trends Ecol Evol 2002, 17(4):183-189.

49. Michel AP, Ingrasci MJ, Schemerhorn BJ, Kern M, Le Goff G, Coetzee M, Elissa N, Fontenille D, Vulule J, Lehmann T, Sagnon N'f, Costantini C, Besansky NJ: Rangewide population genetic structure of the African malaria vector Anopheles funestus. Mo Ecol 2005, 14:4235-4248.

50. Cohuet A, Dia I, Simard F, Raymond M, Rousset F, Antonio- Nkondjio C, Awono-Ambene PH, Wondji CS, Fontenille D: Gene flow between chromosomal forms of the malaria vector Anopheles funestus in Cameroon, Central Africa, and its relevance in malaria fighting. Genetics 2005, 169:301-311.

51. Ayala D, Le Goff G, Robert V, Jong PD, Takken W: Population structure of the malaria vector Anopheles funestus (Diptera: Culicidae) in Madagascar and Comoros. Acta Trop 2006, 97:292-300.

52. Temu EA, Hunt RH, Coetzee M: Microsatellite DNA polymorphism and heterozygosity in the malaria vector mosquito Anopheles funestus (Diptera: Culicidae) in east and southern Africa. Acta Trop 2004, 90:39-49.

53. Lehmann T, Hawley WA, Kamau L, Fontenille D, Simard F, Collins FH: Genetic differentiation of Anopheles gambiae populations from east and west Africa: comparison of microsatellite and allozyme loci. Heredity 1996, 77:192-200.

54. Lehmann T, Besansky NJ, Hawley WA, Fahey TG, Kamau L, Collins FH: Microgeographic structure of Anopheles gambiae in western Kenya based on mtDNA and microsatellite loci. Mol Ecol 1997, 6:243-253.

55. Chen H, Minakawa N, Beier J, Yan G: Population genetic structure of Anopheles gambiae mosquitoes on Lake Victoria islands west Kenya. Malaria J 2004, 3:48. 
56. Donnelly MJ, Townson $\mathrm{H}$ : Evidence for extensive genetic differentiation among populations of the malaria vector Anopheles arabiensis in east Africa. Insect Mol Biol 2000, 9:357-367.

57. Ndo C, Antonio-Nkondjio C, Cohuet A, Ayala D, Kengne P, Morlais I, Awono-Ambene HP, Couret D, Ngassam P, Fontenille D, Simard F: Population genetic structure of the malaria vector Anopheles nili in sub-Saharan Africa. Malar J 2010, 9:161.

58. Antonio-Nkondjio C, Ndo C, Kengne P, Mukwaya L, Awono-Ambene HP, Fontenille D, Simard F: Population structure of the malaria vector Anopheles moucheti in the equatorial forest region of Africa. Malar J 2008, 7:120.

doi:10.1186/1756-3305-5-188

Cite this article as: Samb et al:: Population genetic structure of the malaria vector Anopheles funestus, in a recently re-colonized area of the Senegal River basin and human-induced environmental changes.

Parasites \& Vectors 2012 5:188.

\section{Submit your next manuscript to BioMed Central and take full advantage of:}

- Convenient online submission

- Thorough peer review

- No space constraints or color figure charges

- Immediate publication on acceptance

- Inclusion in PubMed, CAS, Scopus and Google Scholar

- Research which is freely available for redistribution 